\title{
May It Please The Court?: The Perils of Correcting a Justice's Pronunciation
}

\author{
James J. Duane*
}

Just after the opening of the Supreme Court's last term, Bryan Garner revisited the perennial peril for appellate advocates: "What should you do if you say something one way and the judge you're appearing before says it another?"1 He celebrated the ingenuity of one advocate who, after hearing Chief Justice William Rehnquist mispronounce the name of a litigant, "made the tactical decision to mispronounce his own client's name in the same way rather than correct the chief justice." 2 Supreme Court observer Tony Mauro likewise gave credit to another attorney who heard a justice say a word in a manner that seemed highly unusual, and then "adopted the same, clearly incorrect pronunciation just to be accommodating." 3 That cautious strategy certainly comports with the Supreme Court's stern admonition to all advocates appearing before that Court: "Do not 'correct' a Justice unless the matter is essential." 4

William Safire once opined: "In the long history of that honorable Court, it is unlikely that any lawyer has corrected a Justice's pronunciation." 5 Safire's educated guess was quite possibly true when he made it, but it is no longer.

Unfortunately, not every lawyer in the nation had the time to read Garner's advice the same day it appeared last fall in the online edition of the ABA Journal. ${ }^{6}$ Only two days later, when I brought some of my law students to observe oral arguments before the Supreme Court of

\footnotetext{
* Professor, Regent University School of Law. Professor Duane is also a faculty member at the National Trial Advocacy College, and a member of the Panel of Academic Contributors to Black's Law Dictionary (10th ed. 2014).

1 Bryan Garner, Is Your Pronunciation on Point?, 101 A.B.A. J. (Nov. 2015).

2 Id.

3 William Safire, When a Justice Needs a Friend, N.Y. Times (Mar. 23, 1997), http://www.nytimes.com/1997/03/23/magazine/when-a-justice-needs-a-friend.html.

4 Guide for Counsel in Cases to Be Argued before the Supreme Court of the UNITED STATES, 9 (2015) https://www.supremecourt.gov/casehand/guideforcounsel.pdf.

5 Safire, supra note 3.

6 Garner, supra note 1.
} 
the United States, we watched as a young and exceptionally talented attorney was unexpectedly thrust into that position and forced to make that terrible tactical choice.

During the argument of one of the cases that morning, Lockhart $v$. United States, one of the justices (in truth, one of the most brilliant members of the Court) referred three times, in a single question, to the antecedent clause in a certain federal statute. Each time, the justice badly mispronounced the word and placed the emphasis on the wrong syllable, "an-TESS-a-dent," as if it rhymed with precedent-an understandable mistake, perhaps, given the similarity of their spellings. (In fact, it sounded like the justice was mentioning some relative named Aunt Tessa Dent.) The pronunciation was so unconventional that I could not have been the only one in the courtroom who needed to hear the word two or three times before having any idea what the justice was trying to say.

In her response to that question, the Assistant to the Solicitor General—who turned in an otherwise exceptional performance arguing the case, and was clearly the best advocate to appear before the Court in either case that morning - gently corrected the justice by saying, not once but twice, "ant-a-SEED-dent." Although I appreciated the clarification for the benefit of my students, the contrast was conspicuous. $^{7}$

After the oral argument, I mentioned that exchange over lunch with my students, and told them that I have never contradicted a judge about the pronunciation of any word while arguing a case. I would instead either mimic the judge's mistaken pronunciation, or simply not use that word in my answer. If possible, I would follow the sagacious example of Justice Elena Kagan, who noted during a recent visit to Harvard Law School that her colleagues on the Supreme Court cannot agree on how to pronounce certiorari, and jokingly confessed that "I sort of plan my sentences never to have to say that word." ${ }^{8}$ After all,

\footnotetext{
7 You can hear the question and the attorney's response on the audio recording of the argument on the Court's website. https://www.supremecourt.gov/oral_arguments/ audio/2015/14-8358 (starting at 48:45). There is no need to mention their names here, because you can listen to the recording if you want such information. But I hope that you will not listen, and will instead take my word for it; it is not my desire to cause anyone any gratuitous embarrassment.

8 Justice Kagan made that comment after politely listening to a first-year law student, Robert, mangle the word rather severely; his question and her amusing response can be heard starting at 1:04:48 in Harvard's recording. https:/www.youtube.com/watch?v $=$ SCLQWtKATpM. Justice Kagan mentioned that she was referring to an article I had written on that topic, and confirmed that I had correctly deduced that she had been intentionally trying to avoid saying that word in public. See James J. Duane, The Proper
} 
there is no need to risk offending someone who will be voting on your case.

The good news for the Assistant to the Solicitor General was that she did not pay too severely for her quiet act of impudence, because she still won the case rather decisively, with only two dissenting justices voting against her. ${ }^{9}$ But that dissenting opinion was written by the same justice whose pronunciation she had been bold enough to respectfully correct, and we can never know for sure whether that was just a coincidence. ${ }^{10}$

The moral of the story is plain. When you argue before the Supreme Court, even if you are a pedantic purist who thinks it is vital to let some justice know about his or her pronunciational peccadillo, it is safer to send that justice a private letter after the case has been decided. Or if you work in the Solicitor General's office and know you will be back before the Court in some other case, better still to say nothing at all and to leave that thankless task to some law professor in the courtroom who does not need to worry about possibly causing any embarrassment to the justices.

That is, after all, why we are here. ${ }^{11}$

Pronunciation of Certiorari: The Supreme Court's Surprising Six Way Split, 17 GREEN BAG 2D 279 (2014).

9 Lockhart v. United States, 136 S. Ct. 958 (2016).

10 The lopsided victory in favor of the Government was perhaps not too surprising, since the United States had also prevailed on the same question before the District Court, and had won a unanimous decision before the Second Circuit Court of Appeals. Indeed, the Government had not lost the vote of a single judge in the history of that case until after it publicly pointed out one of the justices' pronunciation errors. Coincidence? We can never know for sure. The careful advocate does not take such chances.

11 In case you were wondering. As most people do. 